\title{
Phosphate and nitrogen fertilization in the production of Barueiro (Dipteryx alata Vog.) seedlings
}

\author{
Erika Katianne Costa Pinho' ${ }^{1}$, Ana Claudia Costa², Cesar Crispim Vilar ${ }^{2}$, Manoel Euzébio de Souza ${ }^{2}$, \\ Aline Borges Vilela Silva ${ }^{1}$, Carlos Henrique Gomes de Oliveira ${ }^{3}$
}

\begin{abstract}
Barueiro (Dipteryx alata Vog.), a fruit tree native to the Brazilian cerrado, has aroused the interest of producers and consumers due to its almond highly appraised and valued by local markets. To obtain quality barueiro seedlings, balanced fertilization is required, with special attention to the supply of phosphorus and nitrogen, essential for seedling growth and establishment in the field. The aim of this study was to evaluate the growth of barueiro seedlings produced with different phosphate and nitrogen concentrations in Nova Xavantina - MT. The experiment was conducted at the seedling nursery of the Mato Grosso State University (UNEMAT), Campus of Nova Xavantina - MT, from December 2017 to April 2018. The experimental design was randomized blocks (DBC), in a $5 \times 2$ factorial scheme, corresponding to 5 phosphorus concentrations and 2 nitrogen concentrations, with 10 treatments, 4 blocks and 10 plants per plot, totalizing 400 seedlings. The applied concentrations were $0,150,300,450$ and $600 \mathrm{mg} \mathrm{kg}^{-1} \mathrm{P}_{2} \mathrm{O}_{5}$ and 0 and $250 \mathrm{mg} \mathrm{kg}^{-1} \mathrm{~N}$. The following variables were evaluated: plant height, plant stem diameter, number of leaves, number of leaflets, fresh and shoot and root dry mass and Dickson's Quality Index. Significant interaction between phosphorus and nitrogen concentrations for all traits evaluated was observed, except for root dry mass. The greatest growth of barueiro seedlings was obtained when the highest phosphorus concentration $\left(600 \mathrm{mg} \mathrm{kg}^{-1} \mathrm{de}_{2} \mathrm{O}_{5}\right)$ was used, associated to nitrogen fertilization of $250 \mathrm{mg} \mathrm{kg}^{-1}$. There was no isolated effect of phosphate fertilization on the growth of barueiro seedlings without nitrogen application.
\end{abstract}

Index terms: Baru. Phosphorus. Nitrogen. Propagation.

Corresponding author: ekcosta03@outlook.com

Received: January 15, 2019 Accepted: October 07, 2019

Copyright: All the contents of this journal, except where otherwise noted, is licensed under a Creative Commons Attribution License.

\section{$(\mathrm{cc}) \mathrm{E} \mathbf{Y}$}

\section{Adubação fosfatada e nitrogenada na produção de mudas de barueiro (Dipteryx alata Vog.)}

\begin{abstract}
Resumo - O barueiro (Dipteryx alata Vog.), frutífera nativa do cerrado, tem despertado o interesse de produtores e consumidores devido a suas múltiplas possibilidades de uso. Para a obtenção de mudas de barueiro com qualidade, é fundamental a realização de adubações equilibradas, destacando-se o fornecimento de fósforo e nitrogênio, essenciais para o crescimento da muda e o estabelecimento no campo. O objetivo deste trabalho foi avaliar o crescimento de mudas de barueiro sob adubação fosfatada e nitrogenada, em Nova Xavantina - MT. O experimento foi instalado e conduzido no viveiro da Universidade do Estado de Mato Grosso (UNEMAT), Câmpus de Nova Xavantina-MT, durante os meses de dezembro de 2017 a abril de 2018. O delineamento experimental utilizado foi em blocos casualizados (DBC), em esquema fatorial $5 \times 2$, correspondendo a 5 concentrações de fósforo e 2 concentrações de nitrogênio, com dez tratamentos, quatro blocos e dez plantas por parcela. As concentrações aplicadas foram 0; 150; 300; 450 e $600 \mathrm{mg} \mathrm{kg}^{-1}$ de $\mathrm{P}_{2} \mathrm{O}_{5}$ e 0 e $250 \mathrm{mg} \mathrm{kg}^{-1}$ de N. Foram avaliadas as variáveis: altura de plantas, diâmetro do caule, número de folhas, número de folíolos, massas fresca e seca da parte aérea e do sistema radicular, e Índice de Qualidade de Dickson. Ocorreu interação significativa entre as concentrações de fósforo e nitrogênio para todas as características avaliadas, exceto para a massa seca da raiz. O maior crescimento das mudas de barueiro foi obtido quando se utilizou a maior concentração de fósforo $\left(600 \mathrm{mg} \mathrm{kg}^{-1}\right.$ de $\left.\mathrm{P}_{2} \mathrm{O}_{5}\right)$, associada à adubação nitrogenada $250 \mathrm{mg} \mathrm{kg}^{-1} \mathrm{~N}$. Não houve efeito isolado da adubação fosfatada no crescimento de mudas de barueiro sem aplicação de nitrogênio.
\end{abstract} Termos para indexação: Baru. Fósforo. Nitrogênio. Propagação.

\footnotetext{
${ }^{1}$ Agronomist, Mato Grosso State University, Campus of Nova Xavantina. Nova Xavantina- MT, Brazil. Emails: ekcosta03@outlook.com ${ }^{\text {(ORCID }}$ 0000-0001-7248-0128); aline.b.vilela.silva@gmail.com ${ }^{\text {(ORCID 0000-0002-8745-7366) }}$

${ }^{2}$ DSc of Agronomy, Professor at the Mato Grosso State University, Campus of Nova Xavantina. Nova Xavantina-MT, Brasil. Email: anaclau-

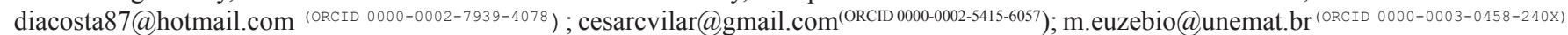
${ }^{3}$ Undergraduate student of the Biological Sciences course, Mato Grosso State University, Campus of Nova Xavantina. Nova Xavantina-MT, Brasil. Email:gomesch5300@hotmail.com (ORCID 0000-0001-9913-6503)
} 


\section{Introduction}

Cerrado, the second largest Brazilian biome, has great diversity of fruit species with economic and ecological potential that have aroused the interest of local industries and small producers (COSTA et al., 2016).

Native fruits of this biome have been poorly studied, lacking studies related to their cultivation, and are still underused due to the lack of scientific knowledge and incentives for their marketing. Thus, much of their exploration is still performed in an extractive manner.

The expansion of studies on the propagation and management of native Cerrado fruits can encourage small and medium producers to establish commercial orchards, generating new sources of income (VERA et al., 2009). Among these fruits, barueiro (Dipteryx alata Vog.) stands out, which is a fruit species belonging to the Fabaceae family, considered a fruit with great potential for cultivation due to the multiple possibilities of use and high seed germination and seedling establishment rate (OLIVEIRA et al., 2017).

Barueiro plants are commonly used for pasture shading, restoration of degraded areas, landscaping and their timber can be used in construction (MARTINOTTO et al., 2012). Both baru pulp and almond can be used for human consumption, and pulp is predominantly composed of starch, insoluble fibers and sugars (OLIVEIRA et al., 2018), in addition to being a promising species for biodiesel production.

To be successful in cultivating native species, information on their propagation is needed. However, there are few recommendations related to the production of barueiro seedlings, especially regarding fertilization recommendation that provides better seedling growth and quality (PINHO et al., 2018).

Seedling formation is an important step in the production process and can provide plants with better performance to withstand adverse field conditions and higher survival rate. Adequate seedling nutrition through balanced fertilization is an important factor to provide greater plant growth and quality (NATALE et al., 2018).

Phosphorus is suitable for seedling production as it plays a key role in photosynthesis and promotes initial root formation and growth, increasing water use efficiency and absorption and utilization of all other nutrients by plants (PRADO, 2008).

Cerrado plants adapt to the low phosphorus availability, which can be achieved by more efficiently using the nutrient present in plant tissue for biomass production (utilization efficiency) or by increasing soil $\mathrm{P}$ acquisition capacity with higher production of root trichomes and other alterations (WANG et al., 2010).

Nitrogen, in turn, composes the chlorophyll molecule, directly participating in photosynthesis, also playing the role of increasing protein content in cells, being generally the nutrient most demanded by plants, being found almost completely complexed in the organic form (SOUZA et al., 2004).

Phosphorus and nitrogen share several functions in plants, among which are the composition of nucleic acids, DNA and RNA, nucleotides used in the energy metabolism of plants such as ATP, phospholipids, NADPH electron carriers, among others, which are fundamental for adequate plant development (FAQUIN, 2005). Thus, it is necessary to supply these two nutrients because the response of one depends on the application of the other to favor plant growth and development (SILVA; TREVIZAM, 2015).

Thus, studies on the fertilization and nutrition of barueiro seedlings are necessary to ensure their quality and encourage the establishment of new orchards, allowing the survival of the species. The aim of this study was to evaluate the growth of barueiro seedlings under phosphate and nitrogen fertilization in Nova Xavantina - MT.

\section{Material and methods}

The experiment was set up and conducted at the seedling nursery of the Mato Grosso State University (UNEMAT), Campus of Nova Xavantina from December 2017 to April 2018. The nursery is located at $14^{\circ} 41^{\prime} 42^{\prime \prime}$ $\mathrm{S}$ and $52^{\circ} 20^{\prime} 08^{\prime \prime} \mathrm{W}$ and $271 \mathrm{~m}$ a.s.l. The climate is Aw (tropical climate with dry winter season) according to the Köppen classification, predominantly tropical, with four months of drought, from May to August, annual average rainfall of $1,750 \mathrm{~mm}$ and average monthly temperature of $28^{\circ} \mathrm{C}$. The total precipitation during the experimental period was $868 \mathrm{~mm}$ and the average temperature was $25.95^{\circ} \mathrm{C}$. The vegetation cover is characterized by the occurrence of two ecological zones, with predominance of Cerrado and Pre-Amazon Transition forests (MARIMON et al., 2010).

The soil used in the experiment was classified as Yellow Latosol (SANTOS et al., 2018) and collected in the experimental area of the Mato Grosso State University, Campus of Nova Xavantina, in the $0-20 \mathrm{~cm}$ layer. After homogenization, a soil composite sample was collected and sent to the laboratory for chemical and physical analysis (Table 1). 
Table 1. Chemical and physical analysis of the soil used as substrate in the production of barueiro seedlings with phosphate and nitrogen fertilization (Nova Xavantina, 2018).

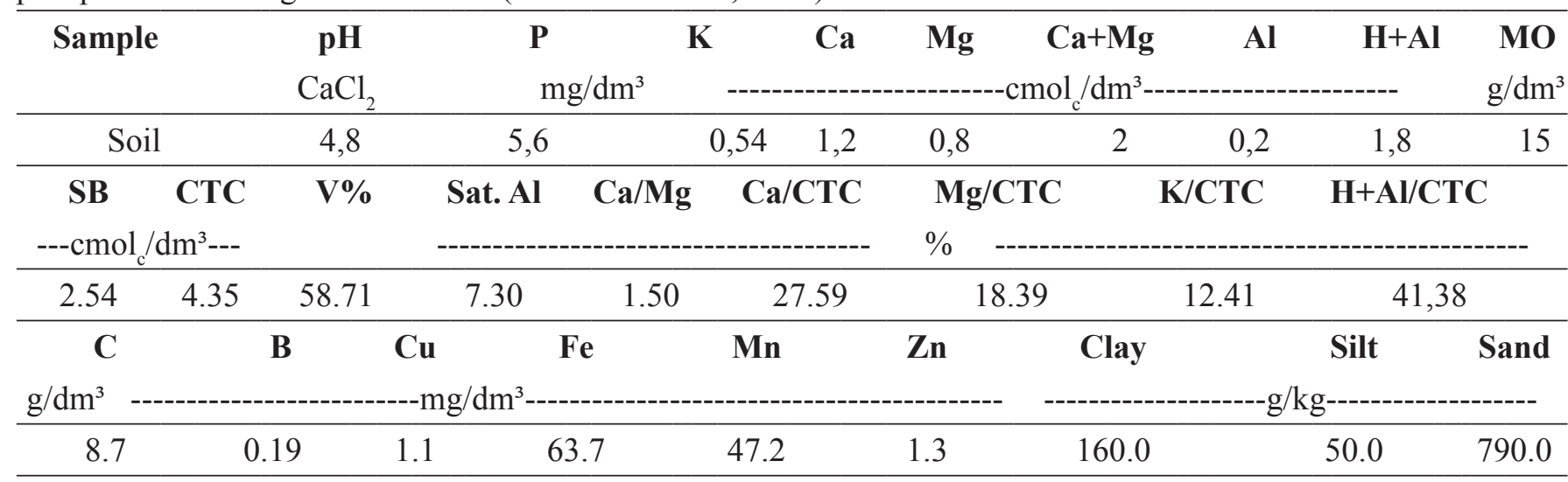

$\mathrm{P}$ and $\mathrm{K}=\mathrm{Mehlich}^{-1} ; \mathrm{Ca}, \mathrm{Mg}$ and $\mathrm{Al}=1 \mathrm{~mol} \mathrm{KCl}$.

Phosphorus and potassium contents obtained by the Mehlich extractor are considered low; $\mathrm{pH}$ characterized as average; cation exchange capacity (CTC) and base saturation are considered adequate and without liming requirement, as interpreted by Souza et al. (2004).

To obtain seeds, ripe baru fruits in good sanitary conditions were collected after their fall to the soil in the "Mário Viana" Municipal Park, municipality of Nova Xavantina-MT. Seeds were extracted with the aid of equipment adapted to the breaking of fruits, avoiding possible damage to them. Seeds were selected considering physical, sanitary aspects and absence of injuries and subsequently disinfected with $2 \%$ bleach and stored in cold chamber, being removed from the cold chamber the day before sowing and kept at $25^{\circ} \mathrm{C}$.

For seedling production, $20 \times 30 \mathrm{~cm}$ polyethylene bags $\left(3.8 \mathrm{dm}^{3}\right)$ filled with previously sieved soil were used, and then bags were placed on metal benches in the $50 \%$ screened nursery shading where 3 seeds per pot were manually sown at approximately $2 \mathrm{~cm}$ in depth.

Twenty days after sowing, seedlings were thinned, keeping only the most vigorous per pot. Irrigation was daily performed with watering can, distributing water evenly in each pot. Weed control was manually performed by eliminating plants soon after emergence to avoid possible competition with seedlings, which remained in the nursery for 120 days after sowing.

The experimental design was randomized block design (RBD) in a $5 \times 2$ factorial scheme ( 5 phosphorus concentrations $\times 2$ nitrogen concentrations), with ten treatments, four blocks with ten plants per plot, totaling 400 seedlings.

Phosphorus concentrations were $0,150,300,450$ and $600 \mathrm{mg} \mathrm{kg}^{-1} \mathrm{P}_{2} \mathrm{O}_{5}$ and nitrogen were 0 and $250 \mathrm{mg}$ $\mathrm{kg}^{-1} \mathrm{~N}$. Simple superphosphate $\left(18 \% \mathrm{P}_{2} \mathrm{O}_{5}, 18 \% \mathrm{Ca}\right.$ and $12 \% \mathrm{~S})$ was used as source of phosphorus and urea (45\% $\mathrm{N})$ as source of nitrogen.
Nitrogen and phosphorus concentrations were calculated in relation to dry soil weight. Phosphate fertilization was weighed separately and the amounts of single superphosphate corresponding to each treatment were mixed with the soil for subsequent filling of polyethylene bags. Nitrogen fertilization was divided into three applications at 30,50 and 70 days after sowing, diluted with water and applied to the substrate approximately $3 \mathrm{~cm}$ away from the plant stem.

At 120 days after sowing, the following agronomic variables were evaluated: plant height $(\mathrm{cm})$, measured with the aid of a millimeter ruler, measuring the distance between the plant stem and the insertion of the last leaf; stem diameter $(\mathrm{mm})$, with the aid of a digital caliper, measuring stem thickness $2 \mathrm{~cm}$ above the neck; number of leaves, number of leaflets, fresh mass (MFPA) and shoot dry mass (MSPA), fresh mass (MFR) and root dry mass (MSR) and Dickson's Quality Index (DQI).

Seedlings were removed from pots, washed in running water and separated into roots and shoots with the aid of pruning shears. Then, the material was placed in paper bags and then weighed separately in analytical scale to determine fresh mass $(\mathrm{g})$, subtracting the mass of the paper bag. The material was taken to the oven with forced air circulation at $65^{\circ} \mathrm{C}$ until it reached constant mass, and then weighed to determine the dry mass of each part.

The Dickson's Quality Index was obtained using methodology proposed by Dickson et al. (1960) applying the equation:

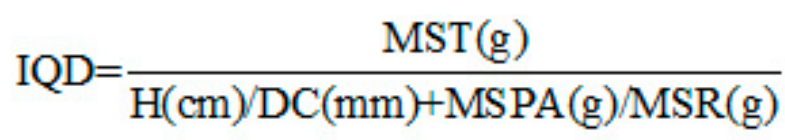

Where: MST: Total dry mass $(\mathrm{g})=($ MSPA + MSR $)$; H: Height (cm); DC: Stem diameter (mm); MSPA: Shoot dry mass (g); MSR: Root dry mass (g). 
Data were submitted to analysis of variance, being the quantitative factor (phosphorus concentrations) analyzed by regression and the comparison of treatments with and without nitrogen obtained by the F test, using the Sisvar software (FERREIRA, 2010).

\section{Results and discussion}

There was a significant interaction between phosphorus $(\mathrm{P})$ and nitrogen $(\mathrm{N})$ concentrations for all evaluated characteristics, except for root dry mass. Then, interactions were evaluated (Table 2).

Table 2. Summary of analysis of variance for plant height (H), stem diameter (D), number of leaves (NF), number of leaflets (NFo), shoot fresh mass (MFPA) and root fresh mass (MFR), shoot and root dry mass (MSPA) and Dickson's quality index (IQD) of barueiro seedlings produced with different phosphorus and nitrogen concentrations. Nova Xavantina, 2018.

\begin{tabular}{ccccccc}
\hline $\begin{array}{c}\text { Sources of } \\
\text { variation }\end{array}$ & $\begin{array}{c}\text { Phosphorus } \\
(\mathbf{P})\end{array}$ & $\begin{array}{c}\text { Nitrogen } \\
(\mathbf{N})\end{array}$ & P x N & Block & Error & CV (\%) \\
\cline { 1 - 5 } GL & 4 & 1 & 4 & 3 & 27 \\
\cline { 1 - 5 } & \multicolumn{5}{c}{ Mean Squares } \\
\cline { 2 - 5 } H (cm) & $35.19^{* *}$ & $395.38^{* *}$ & $10.12^{*}$ & $11.47^{*}$ & 3.47 & 6.11 \\
D (mm) & $0.55^{* *}$ & $5.20^{* *}$ & $0.24^{*}$ & $0.05^{\text {ns }}$ & 0.07 & 4.94 \\
NF & $0.43^{*}$ & $8.64^{* *}$ & $0.52^{*}$ & $0.04^{\text {ns }}$ & 0.14 & 4.83 \\
NFo & $40.24^{* *}$ & $624.65^{* *}$ & $52.11^{* *}$ & $56.35^{* *}$ & 8.25 & 5.08 \\
MFPA & $68.29^{* *}$ & $727.26^{* *}$ & $38.53^{* *}$ & $0.65^{\text {ns }}$ & 3.19 & 9.64 \\
MFR (g) & $5.05^{* *}$ & $0.06^{\text {ns }}$ & $3.01^{*}$ & $2.04^{\text {ns }}$ & 1.09 & 12.74 \\
MSPA (g) & $8.94^{* *}$ & $100.42^{* *}$ & $4.33^{* *}$ & $0.05^{\text {ns }}$ & 0.93 & 15.11 \\
MSR (g) & $0.51^{\text {ns }}$ & $0.03^{\text {ns }}$ & $0.20^{\text {ns }}$ & $0.18^{\text {ns }}$ & 0.23 & 16.60 \\
IQD & $0.09^{*}$ & $0.34^{* *}$ & $0.08^{*}$ & $0.00^{\text {ns }}$ & 0.02 & 13.42 \\
\hline
\end{tabular}

${ }^{\mathrm{ns}}$ not significant, ${ }^{*}$ significant at $5 \%$ probability, ${ }^{* *}$ significant at $1 \%$ probability.

Evaluating the effect of nitrogen fertilization on each phosphorus concentration, higher seedling growth was observed in treatments that received $\mathrm{N}$, in all evaluated characteristics, except for root dry and fresh mass (Figures 1, 2, 3, 4 and 5).

Linear growth was observed for height and diameter of barueiro seedlings as phosphorus concentrations increased when nitrogen application was performed. In the absence of nitrogen fertilization, regression was not significant and the average obtained was $27.37 \mathrm{~cm}$ for height and $5.08 \mathrm{~mm}$ for stem diameter (Figures 1A and 1B).

Seedlings fertilized with $\mathrm{N}$ presented height and stem diameter growth rate of $0.013 \mathrm{~cm} \mathrm{mg}{ }^{-1} \mathrm{P}_{2} \mathrm{O}_{5}$ and $0.001 \mathrm{~mm} \mathrm{mg}^{-1} \mathrm{P}_{2} \mathrm{O}_{5}$ added to the substrate, respectively. Therefore, greater height and stem diameter was verified for seedlings fertilized with $\mathrm{N}$ when the highest $\mathrm{P}$ concentration (600 $\mathrm{mg} \mathrm{kg}^{-1} \mathrm{P}_{2} \mathrm{O}_{5}$ ) was applied. Comparing treatments that did not receive phosphorus, with or without nitrogen, greater height of plants that received $\mathrm{N}$ was observed. These results might have occurred because nitrogen is the limiting nutrient, which according to the "Law of Minimum" can affect plant growth because it is an essential element present in concentrations lower than that required (RAIJ, 1981).

The addition of adequate nitrogen and phosphorus concentrations may promote increases in plant growth
(SATTARI et al., 2014). Phosphorus and nitrogen play many roles in plants, both being present in the composition of nucleic acid molecules (DNA and RNA) that have nitrogen base chains linked by phosphate molecules and in plasma membranes that have phospholipids, essential components of biological membranes, where phosphate is bound to organic compounds by diester bonds. An example of phospholipid is lecithin, which contains a nitrogen molecule in its composition (FAQUIN, 2005). Thus, if $\mathrm{N}$ available to the plant is insufficient, $P$ fertilization may not result in stem height and diameter increments, since DNA, RNA and phospholipid molecules condition plant growth.

In experiments with seedling production, it is important to evaluate features such as plant height and stem diameter during growth, since for successful establishment of field plantations, seedlings must have adequate size and thickness so that they are not easily damaged by pests, diseases or climatic factors (CARGNELUTTI FILHO et al., 2012).

Eight month-old barueiro seedlings submitted to four phosphorus concentrations $(0,150,300$ and 600 $\mathrm{mg} \mathrm{dm}{ }^{-3} \mathrm{P}_{2} \mathrm{O}_{5}$ ) associated with two proportions of cattle manure (10 and $20 \% \mathrm{v} / \mathrm{v})$ in nursery, showed no response to phosphate fertilization for plant height (PACHECO, 2008). The author also observed that nitrogen fertilization (50, 100 and $200 \mathrm{mg}$ seedling ${ }^{-1}$ month $^{-1}$ ) combined with the same proportions of cattle manure promoted a positive 

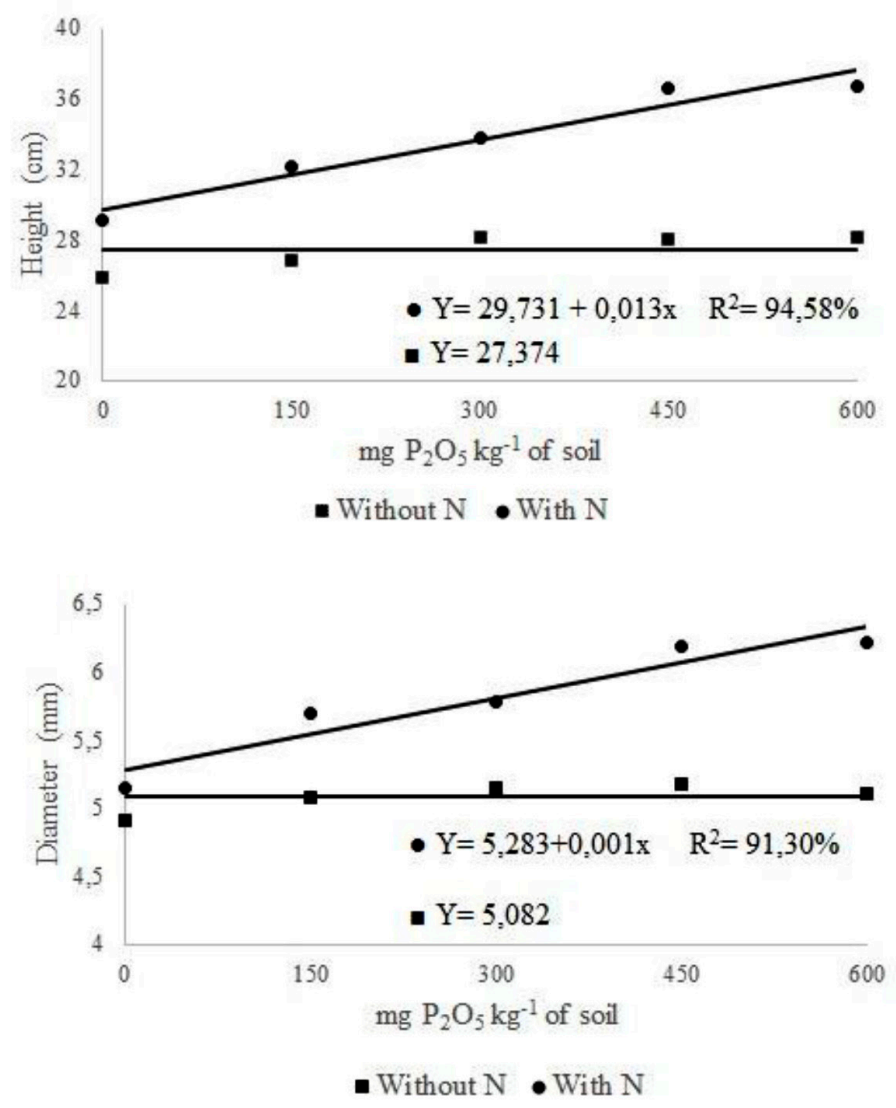

Figure 1. Height (A) and stem diameter (B) of barueiro seedlings produced with different phosphorus and nitrogen concentrations (Nova Xavantina, 2018). Averages followed by the same letter vertically do not differ from each other by the F test.

response to seedling height, stem diameter and shoot dry mass growth.

Silva (2018) verified larger stem diameter of barueiro seedlings produced with the application of $200 \mathrm{mg} \mathrm{dm}^{-3} \mathrm{~N}$ associated with $30 \mathrm{mg} \mathrm{dm}^{-3} \mathrm{~S}$. The same author recommended the use of $300 \mathrm{mg} \mathrm{dm}^{-3} \mathrm{P}_{2} \mathrm{O}_{5}$, which provided stem diameter of $6.75 \mathrm{~mm}$.

Boni et al. (2016) evaluated leaf nutrient contents in barueiro seedling grown under full sun or in protected cultivation on substrate conditioned or not with organic residue and with different phosphorus concentrations $(0$, 100,200 and $300 \mathrm{mg} \mathrm{dm}^{-3} \mathrm{P}_{2} \mathrm{O}_{5}$ ) and found that seedlings were undemanding in phosphorus. Considering the leaf $\mathrm{P}$ contents observed in seedlings produced, the authors stressed the importance of phosphate fertilization so that adequate amounts are available to plants. However, higher P availability was not always reflected in higher leaf $\mathrm{P}$ contents in Dipteryx alata shoots, indicating low plant demand.

Tamarind (Tamarindus indica L.) seedlings fertilized with $\mathrm{P}\left(10,000 \mathrm{mg} \mathrm{P}_{2} \mathrm{O}_{5} \mathrm{dm}^{-3}\right.$ substrate), when $\mathrm{N}$ is applied ( $800 \mathrm{mg} \mathrm{dm}^{-3}$ substrate) showed higher growth, and the combined application of both nutrients is recommended to obtain the largest average length of seedlings of this species (SOUZA et al., 2007). In another study, nitrogen and phosphorus were the nutrients that most affected the growth of barueiro seedlings under nutritional limitations, demonstrating their importance for plant development (SOUSA et al., 2018).

Cerrado plants, such as barueiro, generally have adaptations to low / medium P availability conditions. In general, these plants present alterations aiming at the conservation of phosphorus use, in which case there may be a decrease in plant growth rate, internal $\mathrm{Pi}$ remobilization from lower activity to higher activity parts, alternative respiration routes, among others, and changes that improve phosphorus acquisition or absorption, such as the secretion of phosphatases for the mineralization of rhizosphere organic $\mathrm{P}$, exudation of organic acids changing $\mathrm{pH}$, higher root growth due to alteration in its architecture, among others (VILAR; VILAR, 2013).

Higher number of baru seedling leaves was obtained using $\mathrm{P}_{2} \mathrm{O}_{5}$ concentration of $433.75 \mathrm{mg} \mathrm{kg}^{-1}$, which provided 8.62 leaves per plant for treatments that received nitrogen fertilization (Figure 2A). In the absence of nitrogen fertilization, there was no effect of phosphorus, and seedlings presented an average of 7.32 leaves.

Regarding the number of leaflets, there was an increasing linear effect for $\mathrm{N}$ fertilized treatments, with an increase of 0.017 leaflets for each $\mathrm{mg} \mathrm{kg}^{-1} \mathrm{P}_{2} \mathrm{O}_{5}$ added, with no effect of phosphorus concentrations for treatments that did not receive nitrogen fertilization, presenting an average of 52.64 leaflets per plant (Figure 2B). 

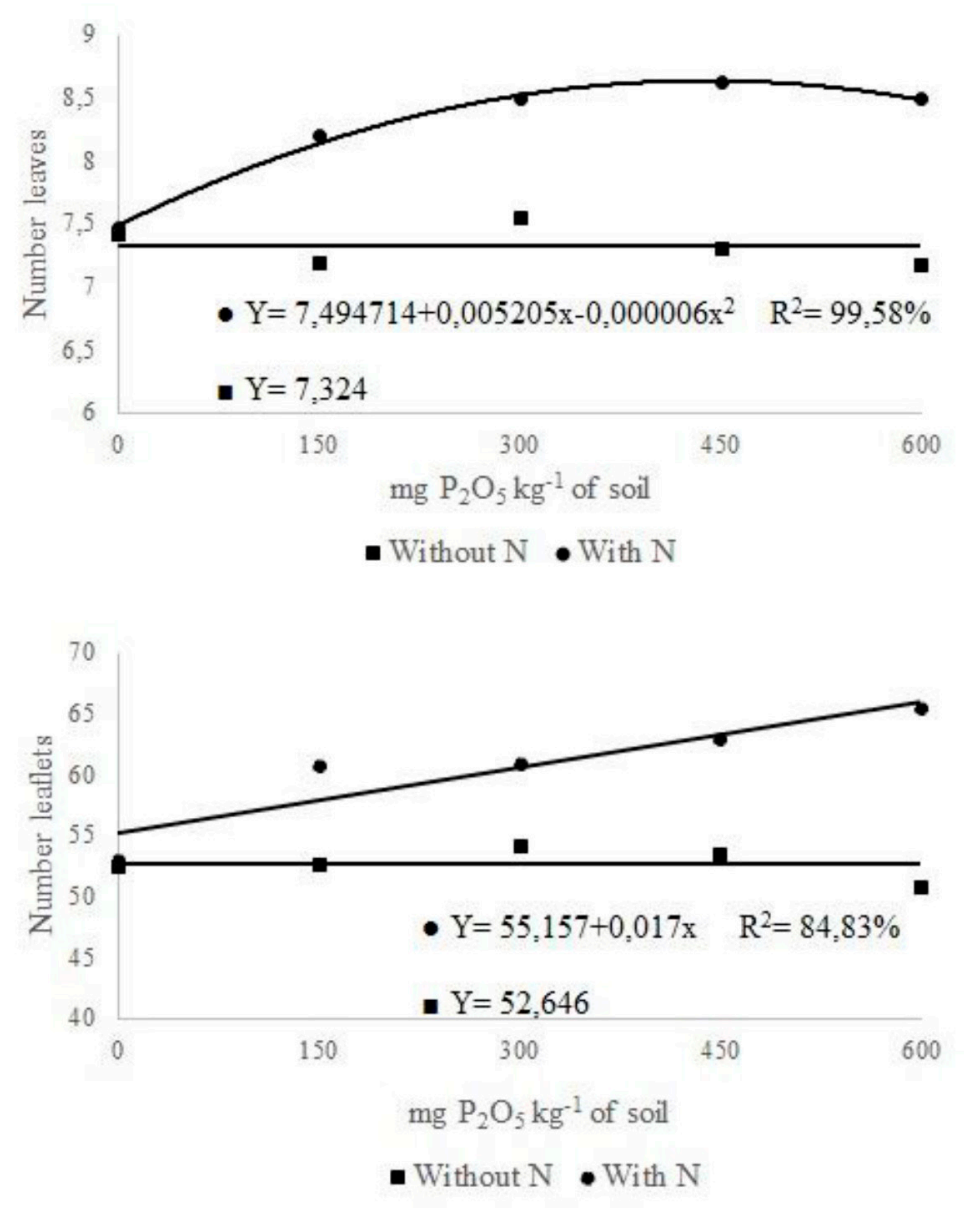

Figure 2. Number of leaves (A) and leaflets (B) of barueiro seedlings produced with different phosphorus and nitrogen concentrations (Nova Xavantina, 2018). Averages followed by the same letter vertically do not differ from each other by the $\mathrm{F}$ test.

Higher number of leaves and leaflets obtained when associated with nitrogen and phosphate fertilization can be attributed to the interaction that occurs between nutrients. $\mathrm{N}$ and $\mathrm{P}$ are constituents of macromolecules such as DNA and RNA, carriers and translators of genetic information. Increases in phosphorus levels incorporated into DNA and RNA indicate increased protein synthesis and cell division. In addition, $\mathrm{N}$ and $\mathrm{P}$ also compose energy molecules such as adenosine triphosphate (ATP), an important compound in which the phosphate group serves to store energy and then transfer it to promote endergonic processes. The ATP molecule consists of adenosine, a nucleoside that contains five $\mathrm{N}$ molecules in its composition, associated with three chain-linked phosphate radicals (MARSCHNER, 1995). Thus, in the absence of $\mathrm{N}$, phosphate fertilization may not result in plant growth, even at low P soils, since both elements share structural functions (MARSCHNER, 1995; FAQUIN, 2005).
Silva (2018) tested different nitrogen $(0,50,100$, 200 and $400 \mathrm{mg} \mathrm{dm}^{-3}$ ) and phosphorus concentrations (150 and $300 \mathrm{mg} \mathrm{dm}^{-3}$ ) in the production of barueiro seedlings and obtained higher number of leaflets (47) using $\mathrm{N}$ concentration of $100 \mathrm{mg} \mathrm{dm}^{-3}$ and 45 leaflets using $\mathrm{P}_{2} \mathrm{O}_{5}$ concentration of $300 \mathrm{mg} \mathrm{dm}^{-3}$, indicating that nitrogen and phosphate fertilization may favor the production of leaflets in the species.

Higher shoot fresh $(27.10 \mathrm{~g})$ and dry $(9.15 \mathrm{~g})$ mass of barueiro seedlings was verified when nitrogen fertilization $\left(250 \mathrm{mg} \mathrm{kg}^{-1} \mathrm{~N}\right)$ was performed in association with concentrations of $595.03 \mathrm{mg}$ and $502.93 \mathrm{mg} \mathrm{P}_{2} \mathrm{O}_{5} \mathrm{~kg}$ ${ }^{-1}$ soil, respectively (Figures $3 \mathrm{~A}$ and $3 \mathrm{~B}$ ). These results indicate the relationship between $\mathrm{N}$ and $\mathrm{P}$, where in the absence of $\mathrm{N}$, there was no effect of phosphate fertilization, even with low soil $\mathrm{P}$ content $\left(5.6 \mathrm{mg} \mathrm{dm}^{-3}\right)$ (Table 1). These results show the importance of understanding the interaction between phosphate and nitrogen fertilization for plant nutrition in Cerrado soils, which lack nutritional information. 

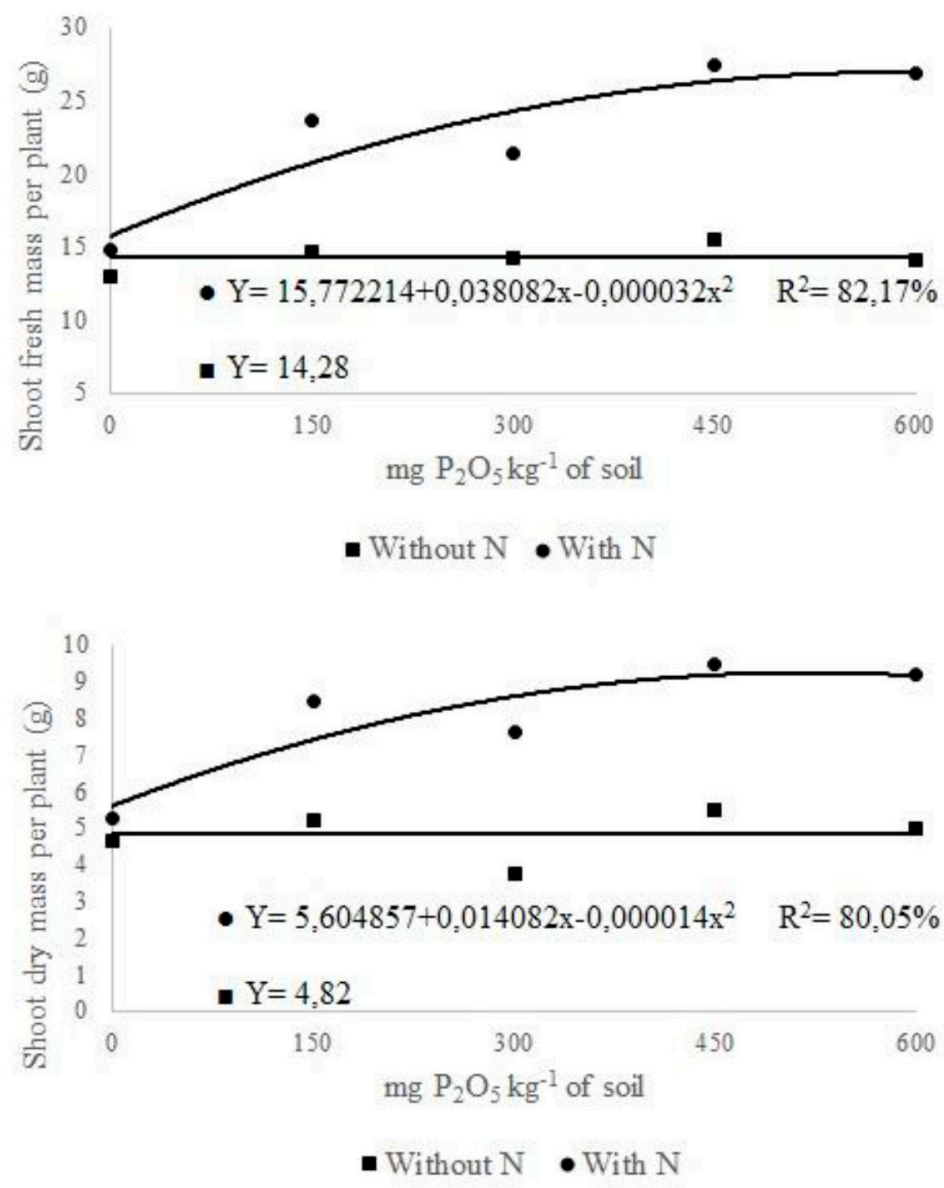

Figure 3. Shoot fresh (A) and dry (B) mass of barueiro seedlings produced with different phosphorus and nitrogen concentrations (Nova Xavantina, 2018). Averages followed by the same letter vertically do not differ from each other by the F test.

In araçazeiro seedlings (Psidium guineense Sw.), species native to the Cerrado, nitrogen fertilization at $300 \mathrm{mg} \mathrm{kg}^{-1}$ substrate concentration, provided higher shoot fresh mass (MARÇAL, 2011), corroborating results of the present work, since there was only phosphate fertilization response in the fresh and dry mass of barueiro seedlings with the addition of $250 \mathrm{mg} \mathrm{kg}^{-1} \mathrm{~N}$. N has structural function and participates in the synthesis of organic compounds, important for plant development (MALAVOLTA, 2006). On the other hand, many native tree species have developed mechanisms for adapting to low soil fertility conditions; however, this issue must be proven by the ability of each species to respond to greater nutrient availability (HARIDASAN, 2008).

Pata-de-vaca seedlings (Bauhinia forficata Link), a pioneer species naturally occurring throughout Brazil, presented higher shoot dry mass when concentrations of $200 \mathrm{mg} \mathrm{dm}^{-3} \mathrm{P}_{2} \mathrm{O}_{5}$ and $75 \mathrm{mg} \mathrm{dm}^{-3} \mathrm{~N}$ were applied ( RAMOS et al., 2000). The maximum shoot dry mass value $(7.14 \mathrm{~g})$ in the initial growth of Stryphnodendron polyphylum (barbatimão) was found at concentrations of $62.46 \mathrm{mg} \mathrm{kg}^{-1} \mathrm{~N}$ and $125.16 \mathrm{mg} \mathrm{kg}^{-1} \mathrm{P}_{2} \mathrm{O}_{5}$ (SOUZA et al., 2014), concentrations below those found in this work for the production of barueiro seedlings, indicating the importance of the association between nutrients ( $\mathrm{N}$ and $\mathrm{P})$ to provide greater growth of native species seedlings.
Figure 4 shows that when nitrogen was applied, the fresh root mass of barueiro seedlings showed linear growth, with increment of $0.005 \mathrm{~g}$ of fresh root mass for each $\mathrm{mg} \mathrm{P}_{2} \mathrm{O}_{5}$ added to the soil. There was no response of phosphate fertilization when no nitrogen was applied, with an average of $8.26 \mathrm{~g}$ in these treatments. There was no interaction of nutrients for dry root mass and no isolated effect of nitrogen and phosphorus application, obtaining an average of $2.93 \mathrm{~g}$. 


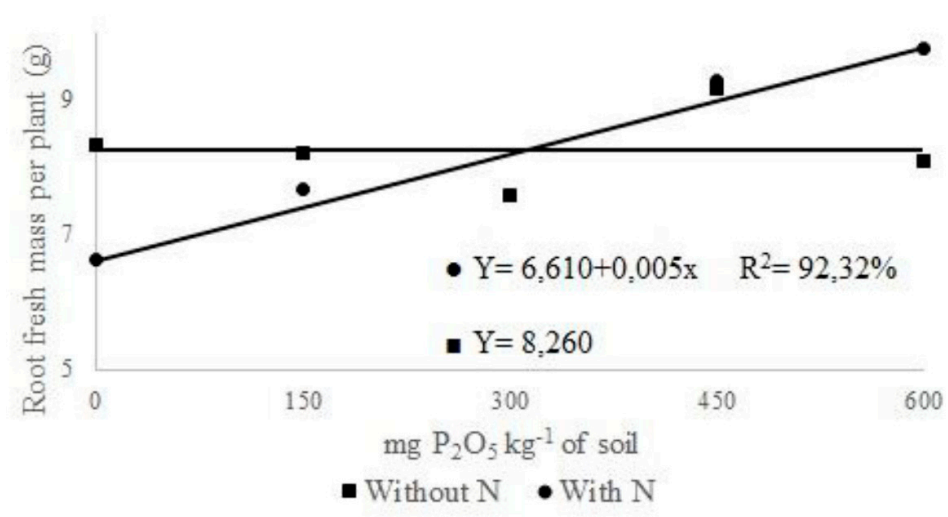

Figure 4. Root fresh mass of barueiro seedlings produced with different phosphorus and nitrogen concentrations (Nova Xavantina, 2018). Averages followed by the same letter vertically do not differ from each other by the F test.

Nutrient availability may affect root system growth and architecture, and in the case of phosphorus deficiency, lateral root growth may be stimulated to the detriment of the primary root (LÓPEZ-BUCIO et al., 2003). This may alter the proportion of water in roots, modifying fresh and dry mass, as verified in the present work, where although higher fresh root mass was observed in plants fertilized with $\mathrm{N}$ at the highest $\mathrm{P}$ concentration, there was no response of fertilization in the root dry mass.

In Schizolobium parahyba (Vell.) Blake seedlings, no significant effects of nutrient application were verified on root dry mass when phosphorus and nitrogen concentrations were applied (LOCATELLI et al., 2007), corroborating results obtained in this work. In contrast, the author observed that the omission of these nutrients caused greater decrease in total dry mass. In the formation of sapotizeiro (Manilkara zapota (L.) P. van Royen) seedlings under phosphorus concentrations $(0 ; 450 ; 900$; $1800 \mathrm{mg} \mathrm{P}_{2} \mathrm{O}_{5}$ per dm${ }^{-3}$ substrate), the nutrient application had no effect on root dry mass production (MENDONÇA et al., 2007).

The Dickson's Quality Index showed an increasing linear model for phosphorus concentrations when nitrogen was applied and in the absence of nitrogen fertilization, there was no significant response to phosphorus concentrations (Figure 5). Seedlings fertilized with $\mathrm{N}$ associated with higher phosphorus concentration $(600 \mathrm{mg}$ $\mathrm{kg}^{-1} \mathrm{P}_{2} \mathrm{O}_{5}$ ) reached DQI of 1.48 .

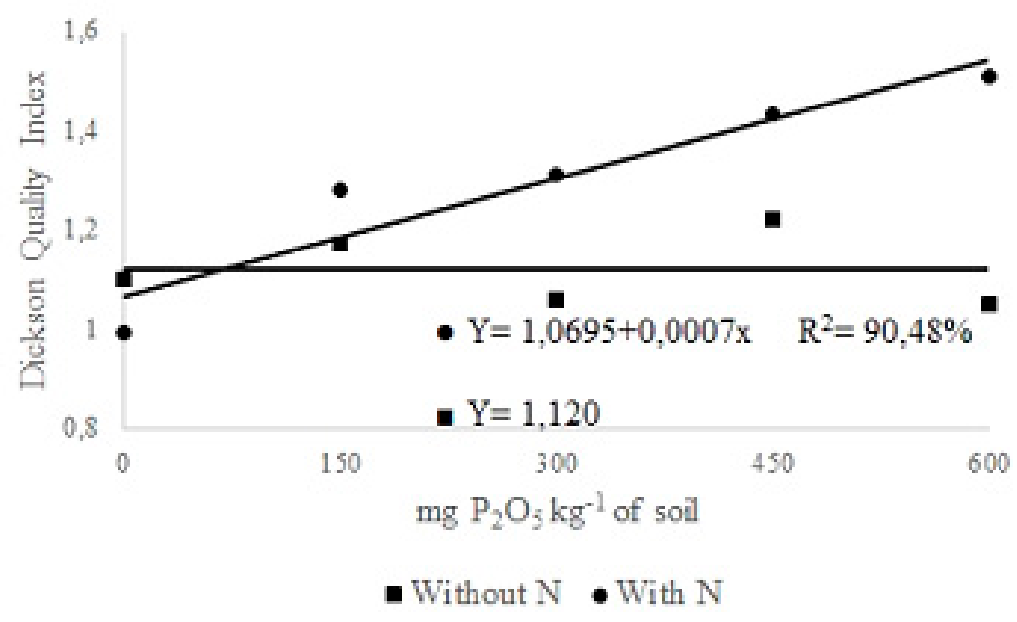

Figure 5. Dickson's Quality Index of barueiro seedlings produced with different phosphorus and nitrogen concentrations (Nova Xavantina, 2018). Averages followed by the same letter vertically do not differ from each other by the F test. 
Barueiro seedlings showed maximum DQI of 1.10, similar to that found in this work, at base saturation of $42.04 \%$ in response to different phosphate fertilization concentrations and base saturation of the substrate, with no significant response of phosphate fertilization for this characteristic (FREITAS, 2013).

Phosphorus and nitrogen interact synergistically because when applied at appropriate concentrations, their combined effect on crop production is generally better than when applied separately (SHUMAN, 2005). In many production systems, nitrogen availability is almost always a limiting factor, influencing plant growth more than any other nutrient (BREDEMEIER; MUNDSTOCK, 2000).
Figure 6 shows the superiority of baru seedlings produced by applying $\mathrm{N}$ associated with $\mathrm{P}$, to the detriment of P-only treatments. In general, these two nutrients added together can be recommended for the production of barueiro seedlings. However, further studies should be carried out using $\mathrm{N}$ and $\mathrm{P}$ concentrations higher than those tested in this work in order to determine those that promote greater growth and quality of barueiro seedlings, which was not always possible with the evaluated concentrations.

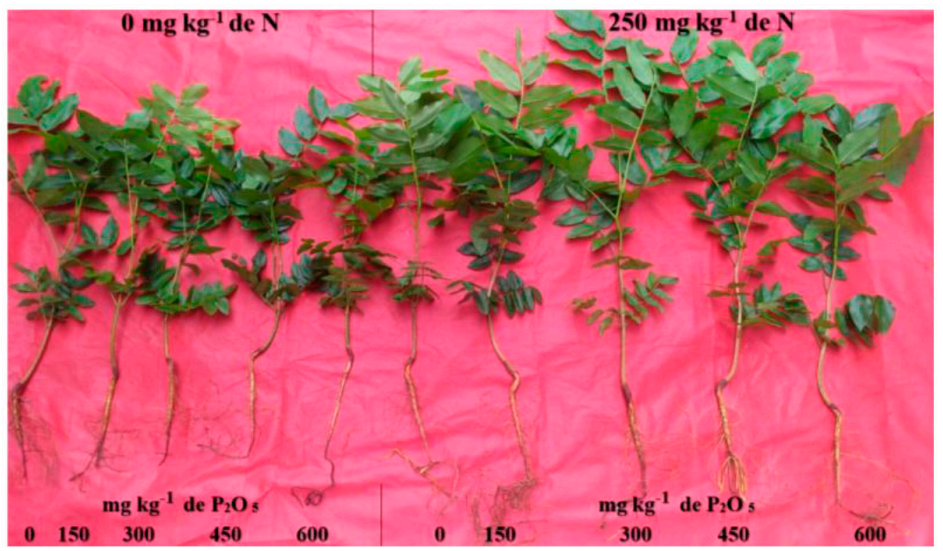

Figure 6. Barueiro seedlings produced with different phosphorus and nitrogen concentrations (Nova Xavantina, 2018).

\section{Conclusion}

Higher growth and quality of barueiro seedlings were obtained when the highest phosphorus concentration (600 mg kg-1 $\mathrm{P}_{2} \mathrm{O}_{5}$ ) associated with nitrogen fertilization $\left(250 \mathrm{mg} \mathrm{kg}^{-1} \mathrm{~N}\right.$ ) was used.

There was no isolated effect of phosphate fertilization on the growth of barueiro seedlings without nitrogen application.

\section{References}

BONI, T.S.; MALTONI, K.L.; BUZETTI, S.; CASSIOLATO, A.M.R. Avaliação comparativa do estado nutricional de mudas de baru (Dipteryx alata). Ciência Florestal, Santa Maria, v.26, n.1, p. 109-121, 2016.

BREDEMEIER, C.; MUNDSTOCK, C. M. Regulação da absorção e assimilação do nitrogênio nas plantas. Ciência Rural, Santa Maria, v.30, n.2, p.365-372, 2000.
CARGNELUTTI FILHO, A.; ARAUJO, M.M.; GASPARIN, E.; AVILA, A.L. Dimensionamento amostral para avaliação de altura e diâmetro de mudas de Cabralea canjerana. Ciência Rural, Santa Maria, v.42, n.7, p.12041211, 2012.

COSTA, E.; OLIVEIRA, L.C.; ESPÍRITO SANTO, T.L.; LEAL, P.A.M. Production of baruzeiro seedling in different protected environments and substrates. Engenharia Agrícola, Jaboticabal, v.32, n.4, p.633-641, 2012.

COSTA, L.T.; RODRIGUES, D.B.; MELO, J.O.F.; TAROCO, H.A.; SOUZA, A.G. Importância dos frutos do Cerrado para a região de Sete Lagoas. In: CONGRESSO BRASILEIRO DE EXTENSÃO UNIVERSITÁRIA, 7., 2016, Ouro Preto. Anais [...]. Ouro Preto: UFOP, 2016. Disponível em: http://www.cbeu.eventsystem.com.br/ gerar_pdf.php?id=2126. Acesso em: 13 jun. 2018.

DICKSON, A.; LEAF, A. L.; HOSNER, J. F. Quality appraisal of white spruce and white pine seedling stock in nurseries. Forest Chronicle, Mattawa, v.36, n.1, p.1013, 1960. 
FAQUIN, V. Nutrição mineral de plantas. 2005. Especialização (Solos e Meio Ambiente) - Lato Sensu à Distância, 2005.

FERREIRA, D. F. Sisvar: sistema de análise de variância. Versão 5.3. Lavras: UFLA, 2010.

FREITAS, E.C.S. Crescimento e qualidade de mudas de Cassia grandis Linnaeus f., Plathymenia foliolosa Benth. e Dipteryx alata Vogel em resposta à adubação fosfatada e saturação por bases do substrato. 2013. Dissertação (Mestrado em Ciência Florestal) Universidade Federal de Viçosa, Viçosa, 2013.

HARIDASAN, M. Nutritional adaptations of native plants of cerrado biome in acid soils. Brazilian Journal of Plant Physiology, Botucatu, v.20, n.3, p.183-195, 2008.

LOCATELLI, M.; MELO, A.S.; LIMA, L.M.L.; VIEIRA, A.H. Deficiências nutricionais em mudas de Schizolobium parahyba var. amazonicum. Revista Brasileira de Biociências, Porto Alegre, v.5, n. 2, p.648-650, 2007.

LÓPEZ-BUCIO, J.; CRUZ-RAMÍREZ, A.; HERRERAESTRELLA, L. The role of nutrient availability in regulating root architecture. Current Opinion in Plant Biology, Oxford, v.6, p.280-287, 2003.

MALAVOLTA, E. Manual de nutrição mineral de plantas. 2.ed. Ouro Fino: Agronômica Ceres, 2006. $638 \mathrm{p}$.

MARÇAL, T.S.; BREMENKAMP, C.A.; ALMEIDAL, A.A.; COELHO, R. I. Efeito da adubação nitrogenada no desenvolvimento de mudas de araçazeiro. In: ENCONTRO LATINO AMERICANO DE PÓS-GRADUAÇÃO, 8., 2011, Paraíba. Anais [...]. Paraíba: Univap, 2011. Disponível em: http://www.inicepg.univap.br . Acesso em: 16 mai. 2018.

MARIMON, B.S.; FELFILI, J.M.; LIMA, E.S.; DUARTE, W.M.G.; MARIMON-JÚNIOR, B.H. Environmental determinants for natural regeneration of gallery forest at the Cerrado/Amazonia boundaries in Brazil. Acta Amazonica, Manaus, v. 40, n. 1, p. 107- 118, 2010.

MARSCHNER, H. Mineral nutrition of higher plants. $2^{\text {nd }}$ ed. London: Academic Press, 1995. 889 p.

MARTINOTTO, F.; MARTINOTTO, C.; COELHO, M.F.B.; AZEVEDO, R.A.B.; ALBUQUERQUE, M.C.F. Sobrevivência e crescimento inicial de espécies arbóreas nativas do Cerrado em consórcio com mandioca. Pesquisa Agropecuária Brasileira, Brasília, DF, v.47, n.1, p.2229, 2012.
MENDONÇA, V.; OLIVEIRA, F.L.; PIO, R.; RUFINI, J.C.M.; CARRIJO, E.P.; RAMOS, J. D. Superfosfato simples e cloreto de potássio na formação de portaenxerto de sapotizeiro [Manilkara zapota (L.) Von Royen]. Ciência e Agrotecnologia, Lavras, v.31, n.1, p.140-146, 2007.

NATALE, W.; LIMA NETO, A.J.; ROZANE, D.E.; PARENT, L.E.; CORRÊA, M.C.M. Mineral nutrition evolution in the formation of fruit tree rootstocks and seedlings. Revista Brasileira de Fruticultura, Jaboticabal, v.40, n.6, p.e-133, 2018.

OLIVEIRA, H.F.E.; SOUZA, C.L.; FÉLIX, D.V.; FERNANDES, L.S.; XAVIER, P.S.; ALVES, L.M. Desenvolvimento inicial de mudas de baruzeiro (Dipteryx alata Vog) em função de substratos e lâminas de irrigação. Irriga, Botucatu, v. 22, p.288-300, 2017.

OLIVEIRA, P.M.; OLIVEIRA, D.E.C.; RESENDE, O.; SILVA, D.V. Study of the drying of mesocarp of baru (Dipteryx alata Vogel) fruits. Revista Brasileira de Engenharia Agrícola e Ambiental, Campina Grande, v.22, n.12, p.872-877, 2018.

PACHECO, A. R. Adubação de mudas de baru (Dipteryx Alata Vog.) em viveiro. 2008. Tese (Doutorado)Universidade Federal de Goiás, Goiânia, 2008.

PINHO, E.K.C.; LOPES, A.N.K; COSTA, A. C.; SILVA, A.B.V.; VILAR, F.C.M.; REIS, R.G.E. Substratos e tamanhos de recipiente na produção de mudas de baruzeiro (Dipteryx alata Vog.). Ciência Agrícola, Rio Largo, v.16, n.1, p.11-19, 2018.

PRADO, R. M. Nutrição de plantas. São Paulo: Unesp, 2008. 407 p.

RAIJ, B. V. Avaliação da fertilidade do solo. Piracicaba: Instituto de Potassa e Fosfato: Instituto Internacional da Potassa, 1981. $142 \mathrm{p}$.

RAMOS, M.RC.; PINTO, J.E.P.B.; FURTININETO,A.E.; DAVIDE, A.C. Influência da aplicação de Nitrogênio, Fósforo e Potássio no crescimento e composição mineral de mudas de Pata-de-vaca (Bauhinia forficata Link). Revista Brasileira de Plantas Medicinais, Botucatu, v.3, n.1, p.79-86, 2000.

SANTOS, H.G.; JACOMINE, P.K.T.; ANJOS, L.H.C.; OLIVEIRA, V.A.; LUMBRERAS, J.F.; COELHO, M.R.; ALMEIDA, J.A.; ARAUJO FILHO, J.C.; OLIVEIRA, J.B.; CUNHA, T.J.F. Sistema brasileiro de classificação de solos. 5.ed. Rio de Janeiro: EMBRAPA, 2018. 353p. 
SATTARI, S.Z.; VAN ITTERSUM, M.K.; BOUWMAN, A.F.; SMIT, A.L.; JANSSEN, B. H. Crop yield response to soil fertility and N, P, K inputs in different environments: Testing and improving the QUEFTS model. Field Crops Research, Amsterdam, v.157, p.35-46, 2014.

SHUMAN, L.M. Mineral nutrition. In: WILKINSON R.E. Plant-environment interactions. New York: Marcel Dekker, 2005.

SILVA, D.S.N. Interação nutricional em mudas de baru e desenvolvimento de plantas sob calagem e doses de P em campo. 2018. Tese (Doutorado) - Universidade Federal de Lavras, Lavras, 2018.

SILVA, M.L.S.; TREVIZAM. A.R. Interações iônicas e seus efeitos na nutrição das plantas. Informações Agronômicas, Piracicaba, n.149, p.10-16, 2015.

SOUSA, F.F.; BRAGA, R.M.; NELSON VENTURIN, N.; MACEDO, R.L.G.; CARLOS, L.; VENTURIN, R.P. Exigências nutricionais de mudas de Dipteryx alata sob limitação nutricional. Ciência Florestal, Santa Maria, v. 28, n. 1, p. 102-114, 2018.

SOUZA, D. M. G.; LOBATO, E. Cerrado: correção do solo e adubação. Brasília, DF: Embrapa Informação Tecnológica; Planaltina: Embrapa Cerrados, 2004. 416 p.
SOUZA, H.A.; PIO, R.; CHAGAS, E.A.; REIS, J.M.R.; RODRIGUES, H.C.A.; RAMOS, J.D.; MENDONÇA, V. Doses de nitrogênio e fósforo na formação de mudas de tamarindo. Bioscience Journal, Uberlândia, v.23, n.1, p.59-64, 2007.

SOUZA, N.H.; MARCHETTI, M.E, THIAGO DE OLIVEIRA CARNEVALI, T.O.; RAMOS, D.D.; SCALON, S.P.Q.; OLIVEIRA, M.T. Crescimento inicial de Stryphnodendron polyphylum (Mart.) em resposta à adubação com N e P. Cerne, Lavras, v.20, n.3, p.441-447, 2014.

VERA, R.; SOARES-JÚNIOR, M.S.; NAVES, R.V.; SOUZA.E.B.; FERNANDES, E.P.; CALIARI, M.; LEANDRO, W.M. Características de amêndoas de barueiros (Dipteryx alata Vog.) de ocorrência natural no Cerrado do Estado de Goiás, Brasil. Revista Brasileira de Fruticultura, Jaboticabal, v.31, n.1, p.112-118, 2009.

VILAR, C.C.; VILAR, F.C.M. Comportamento do fósforo em solo e planta. Campo Digital, Campo Mourão, v. 8, p.37- 44, 2013.

WANG, X.; SHEN, J.; LIAO, H. Acquisition or utilization, which is more critical for enhancing phosphorus efficiency in modern crops. Plant Science, New York, n.179, p.302306 